\title{
The emerging role of physiologically-based pharmacokinetic/biopharmaceutics modeling in formulation development
}

\author{
Sandra Cvijič ${ }^{*}$ Jelisaveta Ignjatović, Jelena Parojčić, Svetlana Ibrić
}

University of Belgrade - Faculty of Pharmacy, Department of Pharmaceutical

Technology and Cosmetology, Vojvode Stepe 450, 11221 Belgrade, Serbia

*Corresponding author: Sandra Cvijić, e-mail: gsandra@pharmacy.bg.ac.rs

\begin{abstract}
Computer-based (in silico) modeling \& simulation tools have been embraced in different fields of pharmaceutics for a variety of applications. Among these, physiologically-based pharmacokinetic/biopharmaceutics modeling (PBPK/PBBM) emerged as a particularly useful tool in formulation development. PBPK/PBBM facilitated strategies have been increasingly evaluated over the past few years, as demonstrated by several reports from the pharmaceutical industry, and a number of research and review papers on this subject. Also, the leading regulatory authorities have recently issued guidance on the use of PBPK modeling in formulation design. In silico PBPK models can comprise different dosing routes (oral, intraoral, parenteral, inhalation, ocular, dermal etc.), although the majority of published examples refer to modeling of oral drugs performance. In order to facilitate the use of PBPK modeling tools, a couple of companies have launched commercially available software such as GastroPlus ${ }^{\mathrm{TM}}$, Simcyp ${ }^{\mathrm{TM}}$ PBPK Simulator and PK-Sim ${ }^{\circledR}$. This paper highlights various application fields of PBPK/PBBM modeling, along with the basic principles, advantages and limitations of this approach, and provides relevant examples to demonstrate the practical utility of modeling \& simulation tools in different stages of formulation development.
\end{abstract}

Keywords: physiologically-based pharmacokinetic modeling (PBPK), physiologically-based biopharmaceutics modeling (PBBM), model informed drug development (MIDD), drug bioperformance

doi.org/10.5937/arhfarm71-32479 


\section{Introduction}

Cost- and time-effective formulation design is an imperative for the highly competitive pharmaceutical industry. In order to handle such challenges, pharmaceutical companies have to move from traditional trial \& error based strategies in formulation development, and adopt novel, more sophisticated methods, such as Quality by Design tools (e.g., design of experiments, machine learning tools) and/or in silico modeling \& simulation $(\mathrm{M} \& \mathrm{~S})$ tools. This last approach is known as model informed drug development (MIDD) and it encompasses a range of quantitative models in formulation development used to facilitate decision making processes (1). MIDD methods are known under different names, depending on the principle and objective of the modeling process. The most commonly used approach refers to the so called physiologically-based pharmacokinetic modeling (PBPK) as a tool to mechanistically interpret and predict absorption, distribution, metabolism and excretion (ADME) properties of drugs in the human body (2). PBPK models can be extended to simulate drugs pharmacodynamic (PD) effects, which are then recognized as PBPK/PD models. More recently, a novel term physiologically-based biopharmaceutics modeling (PBBM) has been introduced to describe the modeling approach primarily orientated toward establishing a link between biopredictive in vitro dissolution testing and mechanistic drug absorption modeling (3). In all of these models, the data derived from preclinical and clinical studies are used to predict the expected biological effects/parameters of interest and clarify the underlying physiological processes.

\section{Structure and performance of PBPK/PBBM models}

Physiologically-based modeling of a drug's ADME properties is based on three sets of input data comprising drug biopharmaceutical (physicochemical and pharmacokinetic) properties, formulation properties and physiological characteristics of the target population/population representative. The necessary input data can be derived from various sources, including experimental (in house data or literature values) and in silico predicted values. The interplay between these parameters and the resulting influence on drug bioperformance is modeled by a series of linked differential equations (4).

The correct representation of the physiology of interest and the underlying physiological processes governing drug bioperformance is a major challenge in the design of PBPK/PBBM models (5). Physiological data are usually extracted from literature and refer to the mean data for the population of interest. However, these data are sometimes difficult to obtain due to the limited information or lack of knowledge, particularly concerning special populations such as paediatrics, geriatrics, pregnant women and various disease populations (6). There has been a number of examples illustrating the use of in house designed PBPK models, including both relatively simple and more complex models (7-11). However, nowadays it is more common to use commercially available software packages such as GastroPlus ${ }^{\mathrm{TM}}$ (https://www.simulationsplus.com/software/gastroplus/), $\quad$ Simcyp $^{\mathrm{TM}} \quad$ PBPK $\quad$ Simulator (https://www.certara.com/software/simcyp-pbpk/) and PK-Sim ${ }^{\circledR}$ (http://www.systems- 
biology.com/products/PK-Sim/). These software packages represent a user-friendly alternative to the in house models, since they integrate relevant physiological data on different populations, along with the required mathematical background, and are ready to use in terms of computer programming.

The available software can be used to simulate drug absorption and/or disposition from different dosage forms, following various administration routes (oral (peroral), intraoral, intravenous, intramuscular, subcutaneous, inhalation, ocular, dermal, intraarticular), at different stages (fasted, fed) and in different population groups regarding age (adults, paediatrics, geriatrics), health and other statuses (healthy, pregnancy state, certain disease states), ethnicity (e.g. Caucasian (Western), Japanese, Chinese populations) and/or enzyme expression levels. Moreover, the simulations can be performed for a population representative, but also for a group of subjects when the model accounts for interindividual variability in the physiological parameters and other input values.

Software from different suppliers have certain specificities, but in general they all comprise representation of major organs/tissues connected with systemic circulation. Figure 1 illustrates an example model integrated in the GastroPlus ${ }^{\mathrm{TM}}$ software package. The Advanced Compartmental Absorption and Transit (ACAT) model provides a detailed representation of the human gastrointestinal (GI) tract and the processes a drug undergoes in different GI regions. The underlying theory and basic principles of the ACAT model have been described in the review papers of Agoram et al. (12) and Lin and Wong (13). The ACAT model is connected with the compartmental pharmacokinetic model (up to three compartments) or full/whole body PBPK model to simulate drug disposition and metabolism. The compartmental model is relatively simple but requires a priory knowledge of drug's pharmacokinetic data (i.e., clearance, volume of distribution, distribution constants). On the other hand, full PBPK model represents a system of organs/tissues, described by relevant physiological parameters, whereat a drug disposition within each organ/tissue is described as either perfusion-limited or permeability-limited, and simulated based on the input drug properties $(14,15)$. 
ACAT model

Compartmental PK model

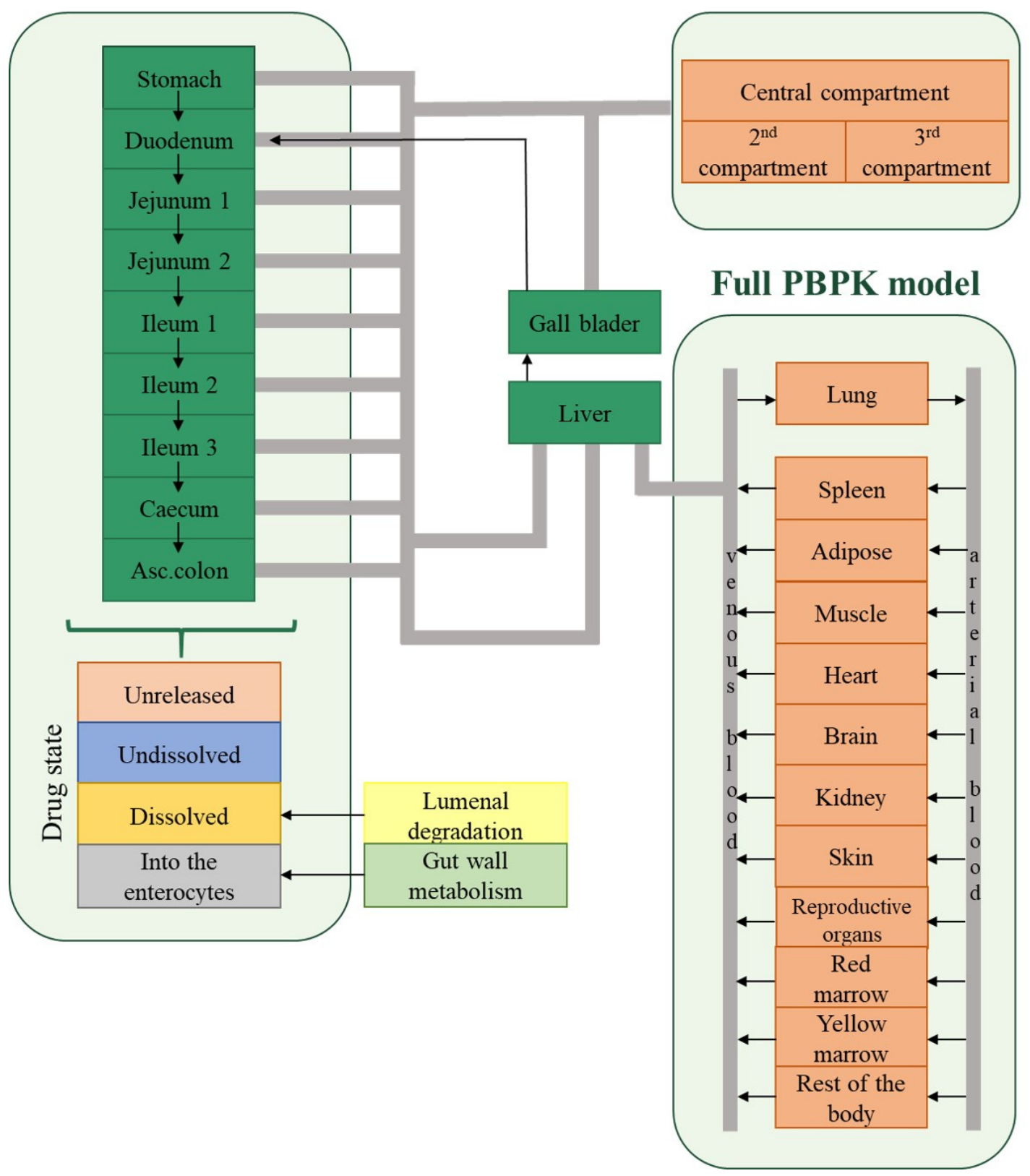

Figure 1. Schematic representation of the models incorporated in GastroPlus ${ }^{\mathrm{TM}}$ software

Slika 1. Shematski prikaz modela inkorporiranih u GastroPlus ${ }^{\mathrm{TM}}$ softver $^{-}$

The software packages are continuously being upgraded, and some of the improvements include the addition of detailed models to describe drug performance following alternative dosing routes. Currently available models (modules) in GastroPlus $^{\mathrm{TM}}$, along with the dosage forms options, are depicted in Figure 2. Most of 
these models are still in a pioneer phase, and there are not many literature reports on their use, although the OCCAT ${ }^{\mathrm{TM}}$ and PCAT $^{\mathrm{TM}}$ models have been explored somewhat more (16-28). The OCCAT ${ }^{\mathrm{TM}}$ model is designed to simulate drug absorption from the oral cavity, and consists of six compartments connected by blood and saliva flows. The model is linked to the ACAT ${ }^{\mathrm{TM}}$ model, in order to predict the absorption of the swallowed dose fraction (16). The PCAT ${ }^{\mathrm{TM}}$ model simulates the processes a drug undergoes in the respiratory tract following intranasal, intratracheal or pulmonary administration. It consists of distinct, but interconnected pulmonary compartments, linked with the rest of the body via systemic circulation to simulate the disposition of drug absorbed through the lungs, and the ACAT ${ }^{\mathrm{TM}}$ model to predict absorption of the swallowed part of the dose (28). PCAT ${ }^{\mathrm{TM}}$ also comprises built-in models to estimate regional drug deposition.

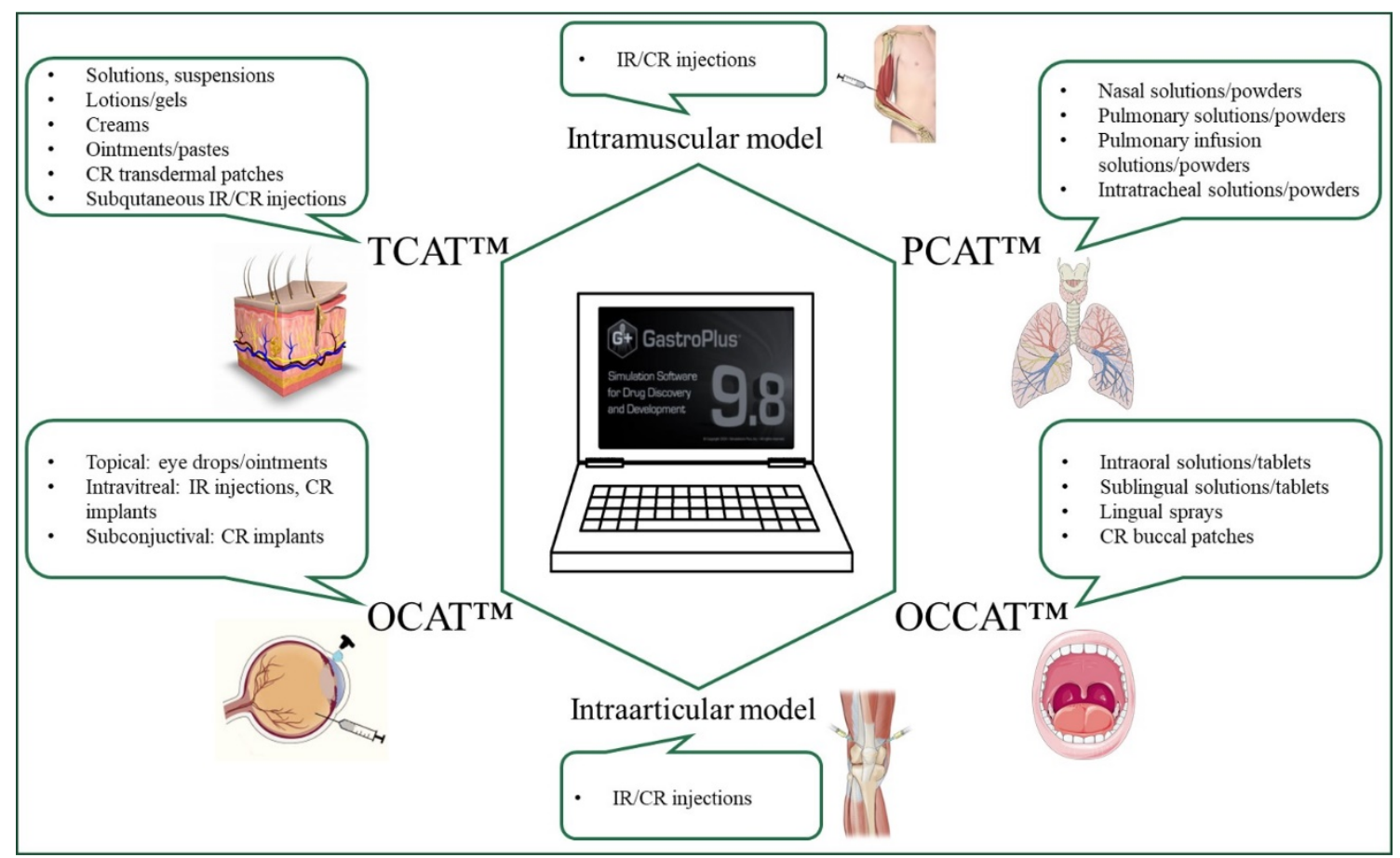

Figure 2. Additional models (modules) in the GastroPlus ${ }^{\text {TM }}$ software (Transdermal Compartmental Absorption and Transit (TCAT ${ }^{\mathrm{TM}}$ ) model; Pulmonary Compartmental Absorption and Transit (PCAT ${ }^{\mathrm{TM}}$ ) model; Ocular Compartmental Absorption and Transit (OCAT ${ }^{\mathrm{TM}}$ ) model; Oral Cavity Compartmental Absorption and Transit (OCCAT ${ }^{\mathrm{TM}}$ ) model; immediaterelease (IR); controlled-release (CR))

Slika 2. Dodatni modeli (moduli) u okviru GastroPlus ${ }^{\text {TM }}$ softvera (Transdermalni prostorni model za simulaciju apsorpcije i transporta lekovite supstance (TCAT ${ }^{\mathrm{TM}}$ ); Prostorni model pluća za simulaciju apsorpcije i transporta lekovite supstance (PCAT ${ }^{\mathrm{M}}$ ); Prostorni model oka za simulaciju apsorpcije i transporta lekovite supstance (OCAT ${ }^{\mathrm{TM}}$ ); Prostorni model usne duplje za simulaciju apsorpcije i transporta lekovite supstance (OCCAT ${ }^{\mathrm{TM}}$ ); trenutno oslobađanje (IR); modifikovano oslobađanje (CR)) 


\section{Modeling principles}

The application field of PBPK/PBBM models is wide, but prior to application a model needs to be set and, if possible, validated. In most cases, this is the lengthiest step of the M \& S process. Each model is drug-specific and the necessary input data have to be collected (preferably experimentally) and carefully analyzed. Also, if some of the parameters are missing, they need to be optimized. The validation phase applies for cases with available reference data from clinical studies. In such cases, clinical data can also be used as inputs in the model (top-down approach) or to refine the model and validate the prediction results (middle-out approach). However, in early phases of drug development, the simulations can be performed solely based on the preclinical and/or in silico predicted data (bottom-up approach), implying that the prediction results might be associated with a level of uncertainty.

The core interest in PBPK/PBBM lies in the ability of these models to predict the expected drug absorption and bioavailability in the formulation development phase, prior to clinical studies, or in line with the post approval changes, to assess the impact of variations in drug product on its bioperformance. Common objectives of PBPK/PBBM modeling are denoted on Figure 3, and the selected examples referring to the use of these models in formulation development are described in the following section.

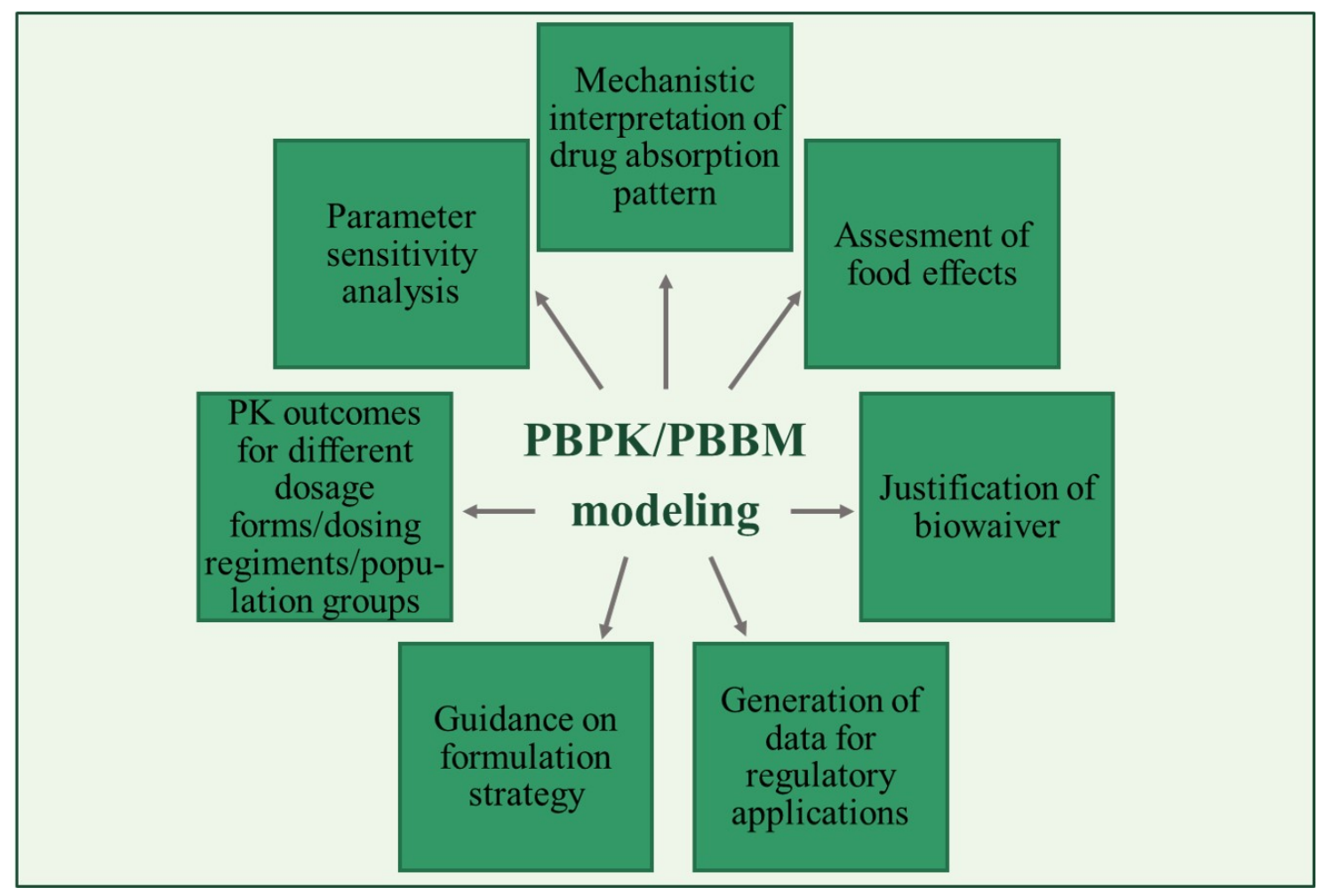

Figure 3. Application of PBPK/PBBM modeling

Slika 3. Primena PBPK/PBBM modelovanja 


\section{Application of PBPK/PBBM modeling in formulation development}

A plethora of published papers demonstrate the emerging role of $\mathrm{M} \& \mathrm{~S}$ tools in pharmaceutical development, mostly for oral dosage forms, but there are also some examples referring to dosage forms for alternative dosing routes.

One of the key features of PBPK/PBBM models is sensitivity analysis (SA) used to assess the sensitivity of output values (e.g., drug's absorption and bioavailability) to the changes in the input variables (e.g., drug and formulation properties such as particle size, solubility, dissolution rate or physiology characteristics such as $\mathrm{GI} \mathrm{pH}$, transit time etc.). In this way, SA allows the identification of critical factors affecting the rate and extent of drug absorption prior to formulation development or assessment of the impact of formulation variations in the post-approval phase. SA can also be used to understand the possible reasons for poor drug bioavailability or inter-subject/inter-population variability. To exemplify, a case study for a poorly soluble candidate drug illustrates the utility of in silico modeling to guide the formulation design of a drug product that would diminish the effect of medium $\mathrm{pH}$ on drug dissolution and absorption. In this case, the model drug was a weak base with $\mathrm{pH}$-dependent solubility in the GI $\mathrm{pH}$ range, implying that patients with achlorhydria or patients taking antacids, H2-blockers or proton pump inhibitors may suffer from reduced drug absorption due to potential precipitation under the elevated gastric $\mathrm{pH}$. Therefore, a drug-specific model was constructed in GastroPlus ${ }^{\mathrm{TM}}$, and $\mathrm{SA}$ for the two selected variables (gastric $\mathrm{pH}$ and drug particle size) revealed that, if particle size is held below a certain limit $(100 \mu \mathrm{m})$, medium $\mathrm{pH}$ is not expected to significantly influence drug dissolution and absorption. This case demonstrated that a relatively simple formulation strategy may overcome problems with reduced drug bioavailability in certain patient groups. Moreover, these in silico data were used to justify drug particle size limits within the quality specification included in the regulatory submission (29). Similar examples on using in silico modeling and SA to establish drug particle size specifications were described in the papers of Wei and associates (30), and Kesisoglou \& Wu (31). Reports on using SA as part of the formulation development strategy are numerous, but they generally consider the assessment of particular model variables. There is also an example of a more general approach applied by Melillo et al. (32) who described the use of in house (MATLAB) created PBPK models in combination with global sensitivity analysis to identify the key parameters affecting the absorption and bioavailability of drugs in relation to their biopharmaceutical properties (i.e., Biopharmaceutics Classification System (BCS) class). According to the modeling results, formulation properties might influence bioperformance of all BCS drug classes, while the absorptionrelated parameters are mainly expected to influence fraction absorbed of poorly permeable drugs.

In extension to SA, PBPK programs also allow population simulations in a group of virtual subjects to anticipate the inter-population or inter-subject variability on drug ADME properties. This approach is particularly useful in the design of dosage forms for special populations e.g., age-appropriate formulations for paediatric patients. For example, Johnson et al. (33) modeled different quetiapine formulations in children and 
adolescents to evaluate the exposure of extended-release (ER) formulation in relation to immediate-release (IR) one. More recently, Vaidhyanathan et al. (34) reported the use of PBPK modeling to evaluate the rate and extent of dasatinib absorption from IR tablet and a pediatric powder for oral suspension. There is also a published example of more specific PBPK modeling for paediatric patients who underwent renal transplantation. The authors tested the scenario when a patient switches from fast-release to sustained-release tacrolimus formulations, and based on the modeling outputs, they were able to provide personalized recommendations on drug dosing (35). PBPK modeling orientated toward providing proper dosing recommendations was also reported for geriatric patients (3638) and certain disease populations (39-41).

Contemporary trends in pharmaceutical development emphasize the benefits of novel drug delivery systems and advanced formulation technologies, and PBPK/PBBM modeling has also been applied to elucidate the outcomes of such formulation approaches. An interesting example refers to the application of PBBM approach to identify simvastatin formulations with increased oral bioavailability. Simvastatin is a poorly soluble lactone prodrug susceptible to extensive pre-systemic metabolism in the gut wall and liver, and in silico modeling revealed that mere improvement in drug solubility (e.g., by formulating drug-loaded self-microemulsifying drug delivery system (SMEDDS)) will have no effect on drug plasma exposure. But, the formulation of oral dosage forms that release the drug in a pre-solubilized form in distal parts of the intestine (e.g., SMEDDS filled in acid-resistant capsules or lipid-based drug delivery systems with polymethacrylate polymers as solid carriers) might improve simvastatin bioavailability by more than $50 \%$ in comparison to conventional IR dosage form $(42,43)$. Another example described the use of in vitro-in silico modeling to assess the potential of solid dispersions to improve the dissolution rate and bioavailability of valsartan. This study suggested that solid dispersion-based oral formulations may largely increase valsartan bioavailability in comparison to conventional IR capsules (44). In vitro-in silico modeling approach was also used to elucidate the combined effect of drug/formulation and physiological factors on ranitidine absorption and optimize the design of gastroretentive floating system for sustained release of ranitidine (45). A review of Yuan et al. (46) summarizes the efforts to characterize the absorption and disposition of nanoparticles for different administration routes using PBPK modeling. This approach is still associated with many challenges but is expected to progress in the future years.

Another way to explore $\mathrm{M} \& \mathrm{~S}$ is to assess the relationship between the in vitro and in vivo data (in vitro-in vivo correlation/relationship, IVIVC/IVIVR) so that in vitro dissolution test can be used to identify drug/formulation factors which may affect the bioperformance of a drug product (47-49). Such an approach can also be used to justify biowaivers i.e., the substitution of the in vivo bioequivalence studies with the relevant in vitro dissolution data (50-52).

It is well known that the bioperformance of certain drug formulations may be affected by concomitant administration of food. The assessment of such interactions by means of in silico modeling has also been described in literature. An in silico study with 
different carbamazepine formulations i.e., IR suspension, IR tablets, ER tablets and ER capsules revealed that the effect of food on drug absorption is formulation-specific (53). The PBPK approach was also utilized in the study of Jereb et al. (54) to assess the effect of food on the bioequivalence between two formulations containing different drug forms (amorphous vs. crystalline). The same research group also published a report on the general utility of PBPK/PBBM modeling to predict the fed state bioequivalence for pharmaceutical products containing different BCS class drugs (55). Additional studies on this subject are also available in literature, and some of them are summarized in the report of Kesisoglou (56).

Examples on the use of PBPK/PBBM modeling in the development of pharmaceutical formulations for additional dosing routes are more recent and still relatively scarce. The oral cavity model was used to predict drug bioavailability and highlight the advantages of various intraoral dosage forms, including sublingual tablets $(16,22)$, orally disintegrating films $(18,19)$, mucoadhesive buccal tablets $(20)$, buccal films (21) and electrospun buccal nanofibrous sheets (17). There are also examples on the use of pulmonary PBPK models to assess the formulation-dependent performance of inhaled drugs $(23,26)$. A study of Merdy et al. (57) described the use of the ocular model to mechanistically explain the interplay between formulation properties (i.e., drug particle size and viscosity) and physiological factors on local dexamethasone bioavailability from ophthalmic suspensions. In addition, Merdy et al. (58) conducted a study to compare the bioperformance of dexamethasone ophthalmic suspensions vs. ophthalmic solutions using the OCAT ${ }^{\mathrm{TM}}$ model. The TCAT ${ }^{\mathrm{TM}}$ model was used to predict drug absorption following transdermal administration of vinorelbine hydrogel formulations, indicating the potential for transdermal application of this drug as an alternative to intravenous dosing in melanoma treatment (59). Another example of using TCAT ${ }^{\mathrm{TM}}$ model refers to determination of risperidone transdermal dose (applied as eutectic mixtures of the drug and the selected fatty acids) which will provide effective drug plasma levels (60). Moreover, a recent study of Mahdi et al. (61) illustrates the use of TCAT ${ }^{\mathrm{TM}}$ modeling, in combination with in vitro experiments, to support the choice of the suitable solvent for rifampicin subcutaneous delivery in the treatment of skin tuberculosis. The attempts to use MIDD for the development of long-acting injectables have been summarized in the report of Sharan et al. (62).

Within this section, we should also note that a number of drug-specific PBPK models are publicly available in the Open Systems Pharmacology repository (http://www.open-systems-pharmacology.org/), and can be used to aid the design of novel formulations.

\section{Regulatory status}

The pharmaceutical industry may largely benefit from PBPK/PBBM modeling just by using this tool for internal decision-making during preformulation and formulation studies. But an important step forward is the inclusion of $\mathrm{M} \& \mathrm{~S}$ data in regulatory submissions. The leading regulatory authorities have recognized the value of PBPK 
modeling, and during the past years they have made a great effort to prepare relevant guidances on PBPK modeling. Recently issued guidances on this subject include:

1. Guideline on the reporting of physiologically based pharmacokinetic (PBPK) modelling and simulation, issued by EMA in December 2018 (effective from July 2019) (63)

2. Physiologically Based Pharmacokinetic Analyses - Format and Content Guidance for Industry, issued by FDA in August 2018 (64)

3. The Use of Physiologically Based Pharmacokinetic Analyses Biopharmaceutics Applications for Oral Drug Product, draft version issued by FDA in October 2020 (65)

Although the regulatory authorities support the use of PBPK modeling, the number of submissions comprising PBPK generated data is still rather limited. Nevertheless, there is a clear trend of increase in such submissions, as illustrated in the published reports. E.g., there were 67 PBPK-based submissions to EMA up to the end 2015, and 109 submissions according to the data from $2016(66,67)$. Somewhat higher scores were reported from FDA, with 96 submissions up to mid-June 2014, 254 submissions up to the end of 2017, and 107 more submissions in 2018-2019 (68,69). Most of these submissions referred to the use of PBPK modeling to assess drug-drug interactions, but also to predict drug absorption and bioavailability in special populations (paediatrics, pregnancy) and disease states (e.g., hepatic impairment, renal impairment, GI disorders), to assess biopharmaceutical aspects of drug delivery (e.g., effect of polymorphism, food effect), understand drug's pharmacokinetic properties and the role of enzymes and transporters, provide dose recommendations, compare the outcomes between different dose strengths and formulations etc.

\section{Future directions}

PBPK/PBBM modeling emerged as a powerful tool for the assessment of drugs/formulation biopharmaceutical properties, opening a new area of research in the field of pharmaceutics. Research groups within academia, research institutions, pharmaceutical industry and regulatory agencies enthusiastically embraced in silico methods, and nowadays a number of publications, reports, guidelines and regulatory submissions stand as a proof of the value of in silico modeling. Yet, in silico modeling is a dynamic and ever-growing methodology, and there is a need for further improvements in this approach.

Due to the lack of data on certain physiological mechanisms, the bioperformance of some drugs cannot be accurately predicted. Similar issues have emerged in PBPK modeling for special populations (e.g., paediatrics, various disease states), when the lack of knowledge on the target population physiology and physiological/pathological processes limits the application of the in silico tools. To fill these knowledge gaps, we 
need novel methods for acquiring relevant data. In recent years, progress has been made in the development of in vitro methods to estimate drug clearance, and kinetics of enzymes- and transporters-mediated processes. Also, novel methods for the assessment of transporter abundance are expected to provide more transporter-related data for the in silico modeling of drug disposition (70). Special emphasis has been put in the design of biopredictive in vitro methods to assess drug dissolution (71-73), and determination of the key GI variables that should be included in biopredictive dissolution testing of oral drugs $(74,75)$. These efforts will determine the future of PBBM modeling, which in turn may lead to certain changes in the current regulatory requirements for biowaivers.

Some of the PBPK models e.g., for additional drug dosing routes (nasal, pulmonary, ocular, dermal) are still in the early development phase, and need to be refined. The inclusion of new features in these models should increase their prediction power, but in order to do so, we need predictive mathematical models to enable the translation of in vitro to in vivo data.

As stated above, regulatory authorities support the use of in silico modeling, and they should continue to encourage the adoption of these tools within the pharmaceutical industry, and submission of PBPK/PBBM-based reports. Furthermore, a wider acceptance of PBPK/PBBM modeling implies the need for interdisciplinary teams with specialized knowledge and diverse expertise. Some recent reports indicate that physiologically-based modeling of biopharmaceutical drug properties has been adopted within undergraduate and postgraduate courses $(76,77)$, and this trend is expected to continue in the future.

Considering the current trends, PBPK/PBBM modeling may soon become a part of the formulation development routine. We may even speculate that current models and software packages will transcend into model-based platforms for pharmaceutical development, which might initiate a transformational change in drug formulation research and development.

\section{Conclusion}

An evident trend in the increased usage of PBPK/PBBM models within the pharmaceutical industry, regulatory agencies and academic/research institutions highlight the benefits of $\mathrm{M} \& \mathrm{~S}$ tools in different phases of drug discovery and formulation development. Numerous examples demonstrate that these tools enable time- and costeffective development of pharmaceutical products, and may facilitate regulatory decision making. In addition, due to the ability to provide data on virtual case studies and virtual population studies, PBPK/PBBM modeling may contribute to the formulation of patienttailored medicines.

Regulatory acceptance of PBPK/PBBM modeling has marked a landmark in the application of these tools within pharmaceutical industry, and we should expect an increased number of regulatory submissions containing in silico data in the near future. 
Physiologically-based in silico models are still improving, and will likely continue to evolve in line with the new knowledge on human physiology and relevant physiological mechanisms. The growing complexity of these models implies the need for an interdisciplinary approach and continuous education of users to obtain adequate modeling skills. However, the fulfillment of these needs may require certain changes in the pharmaceutical industry organization structure, and refinement of educational (especially postgraduate) study programs.

\section{Acknowledgement}

The authors acknowledge the support of the Ministry of Education, Science and Technological Development, Republic of Serbia (grant number 451-03-9/202114/200161).

\section{References}

1. Wang Y, Zhu H, Madabushi R, Liu Q, Huang SM, Zineh I. Model-informed drug development: current US regulatory practice and future considerations. Clin Pharmacol Ther. 2019;105(4):899-911.

2. Reddy MB, Clewell III HJ, Lave T, Andersen EM. Physiologically based pharmacokinetic modeling: a tool for understanding ADMET properties and extrapolating to human. New Insights into Toxic Drug Test. 2013; p 197-217.

3. Bermejo M, Hens B, Dickens J, Mudie D, Paixão P, Tsume Y, et al. A mechanistic physiologicallybased biopharmaceutics modeling (PBBM) approach to assess the in vivo performance of an orally administered drug product: From IVIVC to IVIVP. Pharmaceutics. 2020;12(1):74.

4. Grbic S, Parojcic J, Djuric Z. Computer-aided biopharmaceutical characterization: gastrointestinal absorption simulation. Computer-aided applications in pharmaceutical technology. Woodhead Publishing Limited; 2013; p 177-232.

5. Kostewicz ES, Aarons L, Bergstrand M, Bolger MB, Galetin A, Hatley O, et al. PBPK models for the prediction of in vivo performance of oral dosage forms. Eur J Pharm Sci. 2014;57(1):300-21.

6. Hartmanshenn C, Scherholz M, Androulakis IP. Physiologically-based pharmacokinetic models: approaches for enabling personalized medicine. J Pharmacokinet Pharmacodyn. 2016;43(5):481-504.

7. Plusquellec Y, Efthymiopoulos C, Duthil P, Houin G. A pharmacokinetic model for multiple sites discontinuous gastrointestinal absorption. Med Eng Phys. 1999;21(8):525-32.

8. Zhang X, Quinney SK, Gorski JC, Jones DR, Hall SD. Semiphysiologically based pharmacokinetic models for the inhibition of midazolam clearance by diltiazem and its major metabolite. Drug Metab Dispos. 2009;37(8):1587-97. 
9. Kambayashi A, Dressman JB. An in vitro-in silico-in vivo approach to predicting the oral pharmacokinetic profile of salts of weak acids: Case example dantrolene. Eur J Pharm Biopharm. 2013;84(1):200-7.

10. Scotcher D, Jones C, Rostami-Hodjegan A, Galetin A. Novel minimal physiologically-based model for the prediction of passive tubular reabsorption and renal excretion clearance. Eur J Pharm Sci. 2016;94:59-71.

11. Patel S, Zhu W, Xia B, Sharma N, Hermans A, Ehrick JD, et al. Integration of precipitation kinetics from an in vitro, multicompartment transfer system and mechanistic oral absorption modeling for pharmacokinetic prediction of weakly basic drugs. J Pharm Sci. 2019;108(1):574-83.

12. Agoram B, Woltosz WS, Bolger MB. Predicting the impact of physiological and biochemical processes on oral drug bioavailability. Adv Drug Deliv Rev. 2001;50:S41-67.

13. Lin L, Wong H. Predicting oral drug absorption: Mini review on physiologically-based pharmacokinetic models. Pharmaceutics. 2017;9(4):41.

14. Theil FP, Guentert TW, Haddad S, Poulin P. Utility of physiologically based pharmacokinetic models to drug development and rational drug discovery candidate selection. Toxicol Lett. 2003;138(1-2):29-49.

15. Jones HM, Rowland-Yeo K. Basic concepts in physiologically based pharmacokinetic modeling in drug discovery and development. CPT Pharmacometrics Syst Pharmacol. 2013;2(8):1-12.

16. Xia B, Yang Z, Zhou H, Lukacova V, Zhu W, Milewski M, et al. Development of a novel oral cavity compartmental absorption and transit model for sublingual administration: illustration with zolpidem. AAPS J. 2015;17(3):631-42.

17. Szabó P, Daróczi TB, Tóth G, Zelkó R. In vitro and in silico investigation of electrospun terbinafine hydrochloride-loaded buccal nanofibrous sheets. J Pharm Biomed Anal. 2016;131:156-9.

18. Chen F, Liu H, Wang B, Yang L, Cai W, Jiao Z, et al. Physiologically based pharmacokinetic modeling to understand the absorption of risperidone orodispersible film. Front Pharmacol. 2020;10:1-10.

19. Drašković M, Turković E, Vasiljević I, Trifković K, Cvijić S, Vasiljević D, et al. Comprehensive evaluation of formulation factors affecting critical quality attributes of casted orally disintegrating films. J Drug Deliv Sci Technol. 2020;56:101614.

20. Kurcubic I, Cvijic S, Filipcev B, Ignjatovic J, Ibric S, Djuris J. Development of propranolol hydrochloride bilayer mucoadhesive buccal tablets supported by in silico physiologically-based modeling. React Funct Polym. 2020;151:104587.

21. Jovanović M, Tomić N, Cvijić S, Stojanović D, Ibrić S, Uskoković P. Mucoadhesive gelatin buccal films with propranolol hydrochloride: Evaluation of mechanical, mucoadhesive, and biopharmaceutical properties. Pharmaceutics. 2021;13(2):1-19.

22. Santos J, Lobato L, Vale N. Clinical pharmacokinetic study of latrepirdine via in silico sublingual administration. Silico Pharmacol. 2021;9(1):29.

23. Wu S, Zellnitz S, Mercuri A, Salar-Behzadi S, Bresciani M, Fröhlich E. An in vitro and in silico study of the impact of engineered surface modifications on drug detachment from model carriers. Int J Pharm. 2016;513(1-2):109-17. 
24. Bäckman P, Tehler U, Olsson B. Predicting exposure after oral inhalation of the selective glucocorticoid receptor modulator, AZD5423, based on dose, deposition pattern, and mechanistic modeling of pulmonary disposition. J Aerosol Med Pulm Drug Deliv. 2017;30(2):108-17.

25. Salar-Behzadi S, Wu S, Mercuri A, Meindl C, Stranzinger S, Fröhlich E. Effect of the pulmonary deposition and in vitro permeability on the prediction of plasma levels of inhaled budesonide formulation. Int J Pharm. 2017;532(1):337-44.

26. Vulović A, Šušteršič T, Cvijić S, Ibrić S, Filipović N. Coupled in silico platform: Computational fluid dynamics (CFD) and physiologically-based pharmacokinetic (PBPK) modelling. Eur J Pharm Sci. 2018;113:171-84.

27. Shi C, Ignjatović J, Liu T, Han M, Cun D, Đuriš J, et al. In vitro - in vivo - in silico approach in the development of inhaled drug products: Nanocrystal-based formulations with budesonide as a model drug. Asian J Pharm Sci. 2021; doi: 10.1016/j.ajps.2020.12.001.

28. Chaudhuri SR, Lukacova V, Woltosz WS. Application of a respiratory PBPK model for predicting deposition and disposition following inhaled administration of morphine. AAPS Annu Meet Expo. 2010;93534. Available from: https://www.simulations-plus.com/assets/ChaudhuriApplication_Respiratory_PBPK_Model_Predicting_Deposition_Disposition_following_Inhaled_A dministration_Morphine-AAPS-2010.pdf.

29. Mathias NR, Crison J. The use of modeling tools to drive efficient oral product design. AAPS J. 2012;14(3):591-600.

30. Wei H, Dalton C, Di Maso M, Kanfer I, Löbenberg R. Physicochemical characterization of five glyburide powders: A BCS based approach to predict oral absorption. Eur J Pharm Biopharm. 2008;69(3):1046-56.

31. Kesisoglou F, Wu Y. Understanding the effect of API properties on bioavailability through absorption modeling. AAPS J. 2008;10(4):516-25.

32. Melillo N, Aarons L, Magni P, Darwich AS. Variance based global sensitivity analysis of physiologically based pharmacokinetic absorption models for BCS I-IV drugs. J Pharmacokinet Pharmacodyn. 2019;46(1):27-42.

33. Johnson TN, Zhou D, Bui KH. Development of physiologically based pharmacokinetic model to evaluate the relative systemic exposure to quetiapine after administration of IR and XR formulations to adults, children and adolescents. Biopharm Drug Dispos. 2014;35(6):341-52.

34. Vaidhyanathan S, Wang X, Crison J, Varia S, Gao JZH, Saxena A, et al. Bioequivalence comparison of pediatric dasatinib formulations and elucidation of absorption mechanisms through integrated PBPK modeling. J Pharm Sci. 2019;108(1):741-9.

35. Prado-Velasco M, Borobia A, Carcas-Sansuan A. Predictive engines based on pharmacokinetics modelling for tacrolimus personalized dosage in paediatric renal transplant patients. Sci Rep. 2020;10(1):1-18.

36. Marsousi N, Desmeules JA, Rudaz S, Daali Y. Usefulness of PBPK modeling in incorporation of clinical conditions in personalized medicine. J Pharm Sci. 2017;106(9):2380-91.

37. Chetty M, Johnson TN, Polak S, Salem F, Doki K, Rostami-Hodjegan A. Physiologically based pharmacokinetic modelling to guide drug delivery in older people. Adv Drug Deliv Rev. 2018;135:85-96. 
38. Rashid M, Sarfraz M, Arfat M, Hussain A, Abbas N, Hussain K, et al. Prediction of pharmacokinetic parameters and dose of pregabalin gastroretentive formulation in healthy adults, healthy pediatrics and renal-impaired geriatrics. J Drug Deliv Sci Technol. 2021;63:102548.

39. Franchetti Y, Nolin TD. Dose optimization in kidney disease: Opportunities for PBPK modeling and simulation. J Clin Pharmacol. 2020;60(S1):S36-51.

40. Kalam MN, Rasool MF, Alqahtani F, Imran I, Rehman AU, Ahmed N. Development and evaluation of a physiologically based pharmacokinetic drug-disease model of propranolol for suggesting model informed dosing in liver cirrhosis patients. Drug Des Devel Ther. 2021;15:1195-211.

41. Rasool MF, Ali S, Khalid S, Khalid R, Majeed A, Imran I, et al. Development and evaluation of physiologically based pharmacokinetic drug-disease models for predicting captopril pharmacokinetics in chronic diseases. Sci Rep. 2021;11(1):1-16.

42. Ćetković Z, Cvijić S, Vasiljević D. In vitro/in silico approach in the development of simvastatinloaded self-microemulsifying drug delivery systems. Drug Dev Ind Pharm. 2018;44(5):849-60.

43. Ćetković Z, Cvijić S, Vasiljević D. Formulation and characterization of novel lipid-based drug delivery systems containing polymethacrylate polymers as solid carriers for sustained release of simvastatin. J Drug Deliv Sci Technol. 2019;53: 101222.

44. Medarević D, Cvijić S, Dobričić V, Mitrić M, Djuriš J, Ibrić S. Assessing the potential of solid dispersions to improve dissolution rate and bioavailability of valsartan: In vitro-in silico approach. Eur J Pharm Sci. 2018;124:188-98.

45. Cvijic S, Ibric S, Parojcic J, Djuris J. An in vitro - in silico approach for the formulation and characterization of ranitidine gastroretentive delivery systems. J Drug Deliv Sci Technol. 2018;45:1-10.

46. Yuan D, He H, Wu Y, Fan J, Cao Y. Physiologically based pharmacokinetic modeling of nanoparticles. J Pharm Sci. 2019;108(1):58-72.

47. Kesisoglou F, Xia B, Agrawal NGB. Comparison of deconvolution-based and absorption modeling IVIVC for extended release formulations of a BCS III drug development candidate. AAPS J. 2015;17(6):1492-500.

48. Ghate VM, Chaudhari P, Lewis SA. Physiologically based pharmacokinetic (PBPK) modelling for in vitro-in vivo extrapolation: Emphasis on the use of dissolution data. Dissolution Technol. 2019;26(3):18-27.

49. Stillhart C, Pepin X, Tistaert C, Good D, Van Den Bergh A, Parrott N, et al. PBPK absorption modeling: Establishing the in vitro-in vivo link-industry perspective. AAPS J. 2019;21(2):1-13.

50. Li X, Yang Y, Zhang Y, Wu C, Jiang Q, Wang W, et al. Justification of biowaiver and dissolution rate specifications for piroxicam immediate release products based on physiologically based pharmacokinetic modeling: An in-Depth analysis. Mol Pharm. 2019;16(9):3780-90.

51. Al-Tabakha MM, Alomar MJ. In vitro dissolution and in silico modeling shortcuts in bioequivalence testing. Pharmaceutics. 2020;12(1):1-16.

52. Wu F, Cristofoletti R, Zhao L, Rostami-Hodjegan A. Scientific considerations to move towards biowaiver for biopharmaceutical classification system class III drugs: How modeling and simulation can help. Biopharm Drug Dispos. 2021;42(4):118-27.

53. Zhang X, Lionberger RA, Davit BM, Yu LX. Utility of physiologically based absorption modeling in implementing quality by design in drug development. AAPS J. 2011;13(1):59-71. 
54. Jereb R, Opara J, Legen I, Petek B, Bajc A, Žakelj S, et al. PBPK absorption modeling of food effect and bioequivalence in fed state for two formulations with crystalline and amorphous forms of BCS 2 class drug in generic drug development. AAPS PharmSciTech. 2019;20(2):1-10.

55. Jereb R, Kristl A, Mitra A. Prediction of fasted and fed bioequivalence for immediate release drug products using physiologically based biopharmaceutics modeling (PBBM). Eur J Pharm Sci. 2020;155:105554.

56. Kesisoglou F. Can PBPK modeling streamline food effect assessments? J Clin Pharmacol. 2020;60(S1):S98-104.

57. Le Merdy M, Fan J, Bolger MB, Lukacova V, Spires J, Tsakalozou E, et al. Application of mechanistic ocular absorption modeling and simulation to understand the impact of formulation properties on ophthalmic bioavailability in rabbits: a case study using dexamethasone suspension. AAPS J. 2019;21(4):1-11.

58. Le Merdy M, Tan ML, Babiskin A, Zhao L. Physiologically based pharmacokinetic model to support ophthalmic suspension product development. AAPS J. 2020;22(2):1-10.

59. de Melo Fonseca A, Araújo CD, da Silva JH, da Silva Honório T, Nasciutti LE, Cabral LM, et al. Development of transdermal based hydrogel formulations of vinorelbine with an evaluation of their in vitro profiles and activity against melanoma cells and in silico prediction of drug absorption. $\mathrm{J}$ Drug Deliv Sci Technol. 2021;63:102449.

60. Al-Akayleh F, Adwan S, Khanfer M, Idkaidek N, Al-Remawi M. A Novel eutectic-based transdermal delivery system for risperidone. AAPS PharmSciTech. 2021;22(1):1-11.

61. Mahdi WA, Hussain A, Altamimi MA, Alshehri S, Bukhari SI, Ahsan MN. Experimental solubility, thermodynamic/computational validations, and GastroPlus-based in silico prediction for subcutaneous delivery of rifampicin. AAPS PharmSciTech. 2021;22(3):116.

62. Sharan S, Fang L, Lukacova V, Chen X, Hooker AC, Karlsson MO. Model-informed drug development for long-acting injectable products: summary of American College of Clinical Pharmacology Symposium. Clin Pharmacol Drug Dev. 2021;10(3):220-8.

63. European Medicines Agency. Guideline on the reporting of physiologically based pharmacokinetic (PBPK) modelling and simulation. 2018. Available from: https://www.ema.europa.eu/en/documents/scientific-guideline/guideline-reporting-physiologicallybased-pharmacokinetic-pbpk-modelling-simulation_en.pdf.

64. FDA. Physiologically Based Pharmacokinetic Analyses - Format and Content. Guidance. 2018. Available from: https://www.fda.gov/files/drugs/published/Physiologically-BasedPharmacokinetic-Analyses-\%E2\%80\%94-Format-and-Content-Guidance-for-Industry.pdf.

65. FDA. The Use of Physiologically Based Pharmacokinetic Analyses-Biopharmaceutics Applications for Oral Drug Product Development, Manufacturing Changes, and Controls Guidance for Industry Draft Guidance. 2020. Available from: https://www.fda.gov/media/142500/download.

66. European Medical Agency. Activity report of the Modelling and simulation working group (MSWG). 2016. Available from: https://www.ema.europa.eu/en/documents/report/2016-activityreport-modelling-simulation-working-group-mswg_en.pdf.

67. Luzon E, Blake K, Cole S, Nordmark A, Versantvoort C, Berglund EG. Physiologically based pharmacokinetic modeling in regulatory decision-making at the European Medicines Agency. Clin Pharmacol Ther. 2017;102(1):98-105. 
68. Grimstein M, Yang Y, Zhang X, Grillo J, Huang SM, Zineh I, et al. Physiologically based pharmacokinetic modeling in regulatory science: An update from the U.S. Food and Drug Administration's Office of Clinical Pharmacology. J Pharm Sci. 2019;108(1):21-5.

69. Wang Y. PBPK Current Status and Challenges: A Regulatory Perspective. 2019. Available from: https://www.fda.gov/media/134099/download.

70. Cvijić S. In Vitro/In Vivo Correlation for Transporters. Hock FJ, Gralinski MR, editors. Drug Discovery and Evaluation: Methods in Clinical Pharmacology. Springer International Publishing; 2019; p. 1-31.

71. Tsume Y, Mudie DM, Langguth P, Amidon GE, Amidon GL. The Biopharmaceutics Classification System: Subclasses for in vivo predictive dissolution (IPD) methodology and IVIVC. Eur J Pharm Sci. 2014;57(1):152-63.

72. Lennernäs H, Lindahl A, Van Peer A, Ollier C, Flanagan T, Lionberger R, et al. In vivo predictive dissolution (IPD) and biopharmaceutical modeling and simulation: Future use of modern approaches and methodologies in a regulatory context. Mol Pharm. 2017;14(4):1307-14.

73. Butler J, Hens B, Vertzoni M, Brouwers J, Berben P, Dressman J, et al. In vitro models for the prediction of in vivo performance of oral dosage forms: Recent progress from partnership through the IMI OrBiTo collaboration. Eur J Pharm Biopharm. 2019;136:70-83.

74. Koziolek M, Garbacz G, Neumann M, Weitschies W. Simulating the postprandial stomach: Physiological considerations for dissolution and release testing. Mol Pharm. 2013;10(5):1610-22.

75. Hens B, Talattof A, Paixão P, Bermejo M, Tsume Y, Löbenberg R, et al. Measuring the impact of gastrointestinal variables on the systemic outcome of two suspensions of posaconazole by a PBPK model. AAPS J. 2018;20(3):1-14.

76. Sutch BT, Romero RM, Neamati N, Haworth IS. Integrated teaching of structure-based drug design and biopharmaceutics: A computer-based approach. J Chem Educ. 2012;89(1):45-51.

77. Romero RM, Bolger MB, Morningstar-Kywi N, Haworth IS. Teaching of biopharmaceutics in a drug design course: Use of GastroPlus as educational software. J Chem Educ. 2020;97(8):2212-20. 


\title{
Uloga fiziološki-zasnovanog farmakokinetičkog/biofarmaceutskog modelovanja u razvoju farmaceutskih preparata
}

\author{
Sandra Cvijić́, Jelisaveta Ignjatović, Jelena Parojčić, Svetlana Ibrić \\ Univerzitet u Beogradu - Farmaceutski fakultet, Katedra za farmaceutsku tehnologiju i \\ kozmetologiju, Vojvode Stepe 450, 11221 Beograd, Srbija
}

*Autor za korespondenciju: Sandra Cvijić, e-mail: gsandra@pharmacy.bg.ac.rs

\begin{abstract}
Kratak sadržaj
Računarski podržano (in silico) modelovanje se danas koristi u različitim oblastima farmaceutskih nauka, sa širokom paletom primene. Kao jedan od in silico alata, fiziološki zasnovano farmakokinetičko/biofarmaceutsko modelovanje (PBPK/PBBM) se pokazalo posebno korisnim u razvoju farmaceutskih preparata. Strategije zasnovane na PBPK/PBBM modelovanju se poslednjih godina sve više razmatraju, što se vidi iz izveštaja farmaceutskih kompanija $i$ velikog broja publikovanih istraživačkih i revijalnih radova na ovu temu. Takođe, vodeće regulatorne agencije su nedavno izdale vodiče koji se odnose na primenu PBPK modelovanja u razvoju farmaceutskih preparata. In silico PBPK modelovanje je primenjivo za različite puteve primene leka (peroralni, (intra)oralni, parenteralni, inhalacioni, okularni, dermalni itd), mada se najveći broj primera iz literature odnosi na modelovanje bioperformansi peroralno primenjenih lekova. Kako bi olakšale primenu PBPK modelovanja, nekoliko kompanija je razvilo komercijalno dostupne programske pakete, kao što su GastroPlus ${ }^{\mathrm{TM}}$, Simcyp ${ }^{\mathrm{TM}}$ PBPK Simulator i PK-Sim ${ }^{\circledR}$. U ovom radu su istaknute različite mogućnosti primene PBPK/PBBM modelovanja, uključujući osnovne principe, prednosti i ograničenja. Takođe, prikazani su odgovarajući primeri koji opisuju praktičnu primenu modelovanja i simulacija u različitim fazama razvoja leka.
\end{abstract}

Ključne reči: fiziološki zasnovano farmakokinetičko modelovanje (PBPK), fiziološki zasnovano biofarmaceutsko modelovanje (PBBM), model zasnovan razvoj lekova (MIDD), bioperformanse lekova 